\title{
Potential of Scale Formation during the Desalination of Power Plant Wastewater in a Bench Scale Evaporator
}

\author{
E Fosso-Kankeu*, K Choku, L Sibiya, T Tamane, N Lemmer, G Gericke, J Redelinhuys and F \\ Waanders
}

\begin{abstract}
Concerned with its impact on the environment, Eskom has implemented policies that work in the interest of preserving water. The 'zero liquid effluent policy' highlights the importance of water recycle and reuse within the electricity generation sector. Eskom utilizes reverse osmosis (RO) to treat power plant wastewater, but this process yields a retentate with high concentrations of scale forming compounds. Multi-effect distillation can serve as a practicable means to treat RO reject water. The scale potential on the heat exchanger surface within an MED system is high, compelling the pre-treatment of the reject solution. In this study, RO reject water collected from a power plant was analyzed to determine the physico-chemical characteristics, including the anion and cation content. The French Creek and the PHREEQC models were then used to predict the formation of scale, as well as the proposal of suitable antiscalants to delay the scale formation. Gypsum and barite saturation levels were high in the feed brine. PMA and HEDP antiscalants were proposed for the $\mathrm{RO}$ reject sample. The saturation indices of scale forming agents were seen to increase for an increase in temperature from $18.5^{\circ} \mathrm{C}$ to $75^{\circ} \mathrm{C}$, as well as during the evaporation of the sample by $34.5 \%$. According to the prediction, HEDP and PMA would be able to control scale formation for $\mathrm{pH}$ variations between 7 and 9, but will not able to control barite scale for any $\mathrm{pH}$ value. Additional treatment is then required to remove barite scale that would form in the MED system.
\end{abstract}

Keywords-Antiscalant, MED (Multi-effect distillation), RO reject, Scale.

Manuscript received September 9, 2019.

$\mathrm{K}$ Choku is with the Water Pollution Monitoring and Remediation Initiatives Research Group at the school of Chemical and Minerals Engineering, North West University, South Africa.

E Fosso-Kankeu is with the Water Pollution Monitoring and Remediation Initiatives Research Group at the school of Chemical and Minerals Engineering, North West university, South Africa.

L Sibiya is with the Water Pollution Monitoring and Remediation Initiatives Research Group at the school of Chemical and Minerals Engineering, North West university, South Africa.

F Waanders is with the Water Pollution Monitoring and Remediation Initiatives Research Group at the school of Chemical and Minerals Engineering, North West university, South Africa

T. Tamane is with the Eskom research facility, Rosherville, South Africa.

G Gericke is with the Eskom research facility, Rosherville, South Africa.

N Lemmer, J Redelinghuys are with the Water Pollution Monitoring and Remediation Initiatives Research Group at the school of Chemical and Minerals Engineering, North West university, South Africa.

\section{INTRODUCTION}

Water scarcity has been the topic of discussion in many fields for decades. South Africa is reported to be one of the driest countries in the world, experiencing almost half of the global average of 860 millimeters of rain per year (amounting to about 500 millimeters per year) [1-29]. Large scale usage of groundwater resources is highly restricted (by almost $80 \%$ ) due to the country's geology [30]. Roughly $8 \%$ of available water in the country is used by the power generation sector (and other large industries). This percentage may seem low, but these industries are situated in water management areas (WMAs) that are strictly water constrained [31]. Knowledge of the energy-water nexus and the problem of water scarcity has led to the analysis of water usage trends within most industries, including the electricity generation sector [32]. In the same breath, Eskom's Acting General Manager made it clear that strategies to reduce the company's water footprint will be implemented, which include the diversification of Eskom's water and energy mix [33]. Over the past decade, waste water recovery and recycle have become very popular to minimize water availability issues. The reclamation of waste water contributes to achieve both volume minimization of liquid waste, and reducing the withdrawal of water (which severely affects ecosystems). By achieving these goals, it is possible for waste water to be viewed as a resource to achieve water sustainability in the near future. A water management strategy that aims to reuse and recycle waste water to minimize the need for disposal comes in the form of the zero liquid discharge (ZLD) strategy. The risks that the disposal of liquid waste poses to the environment are emphasized by this strategy [34]. The costs associated with waste water disposal due to regulations seem to outweigh the costs incurred by implementing ZLD [35]. ZLD processes that are thermal-based are energy-intensive, thus reverse osmosis (RO) has been introduced as a precursor to lower this energy requirement [34]. To prevent rupture, RO membranes are only operated at pressures up to between 55 and 80 bars. To ensure that the osmotic pressure is below this limit, the salinity of the retentate should not exceed $70000 \mathrm{ppm}$ [36][37]. It then follows that there are two main challenges that Eskom needs to tackle. Firstly, Eskom needs to comply with ZLD stipulations stated in their policies, which stipulate that 
salts be disposed of onsite and that the disposal of liquid waste into the environment is forbidden. Secondly, a drop in the target for raw water consumption from 1.39 to 1.34 liters per kilowatt hour, has elevated the significance of waste water reclamation [38]. The main factors that contribute to the dangers of waste water for the environment include the salinity level, temperature and residual additives. The residual additives that are found in brines usually come in the form of antiscalants, which have a low degradability, hence making them dangerous to the surrounding environment. RO reject that is discarded can cause variations in $\mathrm{pH}$ of water resources, the spread of heavy metals and even eutrophication [39]-[40]. Evaporative thermal desalination processes have been successful in treating RO concentrate, and hybrid systems combining membrane and thermal processes have achieved water recoveries of up to $99 \%$ - given that the feed brines were pretreated to reduce scaling. Multi-effect distillation (MED) systems, specifically, are thermal desalination technologies, based on fluid mechanics and the mechanisms of heat transfer. Multiple cells make up a typical MED system, wherein the pressure, as well as temperature, decreases from effect - to - effect. The heat source for the next step is the water vapor that rose from the previous step [41]. Horizontal tube falling film MED systems often experience scaling problems, with scale being deposited on the outside of the heat exchanger tubes. As a result of scale formation, the thermal resistance of the tubes is increased, decreasing the performance of the system. Oversizing the heat transfer surface and adding chemical additives are some methods used in industry to minimize scaling, which unfortunately result in high capital and operating costs [42]. The factors to pay attention to that affect scaling in MED systems consist of the composition of the feed fluid, the thermal field, the flow field and the surface properties of the heat exchange surface. Investigating the limitations of the optimum process conditions, as well as adding chemical additives constitute an effective strategy in combating scaling. Furthermore, the pretreatment method is affected by the characteristics of the RO feed brine. The compounds of interest, in the brine characterization, are those that are most likely to form scale on the heat exchanger surface. These compounds mainly include calcite (all three polymorphs), anhydrite, gypsum and silica [43]. Any variations in the brine characteristics can result in changes in the composition and concentration level of resulting brine. Scale is typically crystalline in nature, exhibiting a surface charge that can be either directly or indirectly dependent on $\mathrm{pH}$ [44]. The $\mathrm{pH}$ has such a large effect on the likelihood of scaling, that a mere change in $\mathrm{pH}$ from 7 (neutral) to 10 (basic) can lead to the premature precipitation of scale forming compounds. Temperature is another important factor when it comes to scale formation, with scale formation said to begin around $30-35^{\circ} \mathrm{C}$ and goes on to increase as temperature is increased. The abovementioned stresses the importance of the pretreatment method being able to handle potential changes in brine characteristics, without compromising the quality of product water [45]. The deciding factor between utilizing a membrane or thermal desalination lies in the total dissolved solids (TDS) content level. At high levels of TDS, about 40000 ppm, in the RO reject, it has been found that thermal desalination technologies are crucial to minimize brine volume [41]. The saturation limits of each salt is to be kept below the upper limit to inhibit scaling in thermal desalination systems. The easiest way to achieve this is to introduce an acid or an antiscalant into the system. Antiscalants are usually made up of either phosphonate, acrylic acid or a blend of the two - in industry [38]. Supersaturation is the driving force for salt precipitation at the heat-and-mass transfer surface of an MED system. This does not mean that all solutions in the supersaturated state will experience precipitation, however. Metastability describes the state of a supersaturated solution that remains supersaturated for an extended period of time or even indefinitely, because nucleation does not occur in this state. The period of time during which the solution is metastable is called the induction period. The degree of supersaturation of the precipitating salt plays a role in how long the induction period of a solution is going to be. Instability of the solution begins at the onset of nucleation [46]. It then follows that, for thermal desalination processes, as the solution becomes more concentrated, the main limiting factor for precipitation is the degree of supersaturation that the solution is able to handle before becoming unstable. The phenomenon of scaling involves crystallization and transport mechanisms, and instead of eliminating the presence of scale forming compounds altogether, rather, antiscalants delay crystallization and retard crystal growth [47]. The main mechanisms of scale inhibition exhibited by antiscalants are known to be threshold action, chelation, dispersion and crystal distortion [44]. Weakening the adherence of scale to the flow surface and inhibiting further crystal growth is the best way to control scaling, which is also known as the threshold inhibition of scale [48]. The knowledge of how scale forms can assist in determining how antiscalants can function to prevent scale formation. The successful use of chemical inhibitors in industry can be attributed to their ease of handling, low dosages and low costs [49]. The optimum dosage of antiscalants is important in that if the dosing rate is too low, the onset of scale formation will occur, while a dosing rate that is too high results in sludge formation [50].

Thus, successful desalination involves the determination of the best type of inhibitor for the feed brine, as well as the optimum dosing rate. The geochemical simulator, PHREEQC, is employed to obtain the metal speciation of RO brine before and after thermal treatment, whereas the French Creek software proposes a suitable anti-scalant for the solution to achieve successful scale control in the MED system.

\section{EXPERIMENTAL PROCEDURE}

\section{A. Water Sampling}

Samples of RO water reject were collected from the Grootvlei Power Station, located in Mpumalanga province. The water samples were collected in $25 \mathrm{~L}$ clean, plastic water containers directly from the reverse osmosis brine sample 
points. The sample points are situated roughly one meter above ground level with valves that can be opened or closed. Each water container was labelled after being filled. Samples were taken from both Train 1 and Train 2 of the RO system. The RO brine samples were covered in black plastic bags to prevent the penetration of external light, and refrigerated to prevent pre-mature precipitation [51-55]. The samples were only kept and used for a maximum of 4 weeks, and were discarded of thereafter.

\section{B. Laboratory Analysis}

The characterization of the samples involved measuring the conductivity, $\mathrm{pH}$ and ORP with the use of the Lovibond SensoDirect 150 multiparameter water quality meter. The Multiparameter Bench Photometer HI 83099 (Hanna Instruments Inc., USA) was used to determine the sulfate concentration in the samples, while the $2100 \mathrm{Q}$ portable turbidimeter was used to measure the turbidity level. Furthermore, the chloride content and total alkalinity were measured by the chloride portable photometer and the handheld colorimeter alkalinity for fresh water (Hanna), respectively. In order to determine which metals were present, as well as their relevant concentrations in the samples, four samples were externally measured using inductively coupled plasma optical emission spectrometry (ICP-OES) (Agilent Technologies, USA) at the Water Lab (Pty) Ltd. This company has received SANAS (South African National Accreditation System) accreditation. Two samples from each train (raw and diluted) were analyzed. Every instrument was calibrated utilizing buffer and standard solutions before being used.

A control water sample was made by dissolving salts to achieve concentrations of $0.005 \mathrm{~mol} / \mathrm{dm}^{3} \mathrm{CaCl}_{2} \cdot 2 \mathrm{H}_{2} \mathrm{O}$ and $0.005 \mathrm{~mol} / \mathrm{dm}^{3} \mathrm{CaCO}_{3}$ in distilled water [56].

\section{Metal Speciation using PHREEQC Modelling}

The speciation of metals in the RO reject samples was predicted using the geochemical modelling software PHREEQC. PHREEQC is open - source modelling package developed by the US Geological Survey. The software requires a chemical database and an input file (that can be modified by the user) to generate chemical equations [57,58]. This modelling software is based on an ion association aqueous model and has advanced capabilities with regards to speciation and saturation calculations. Given this, PHREEQC determines and reports the speciation of metals in a sample in terms of their inorganic complexes and free hydrated ions in order to identify the scaling potential of aqueous solutions [59]. The MINTEQ database, one amongst many offered by PHREEQC, was used in this study. A PHREEQC analysis was conducted on both the raw sample and the concentrated brine from evaporation to predict the effect of evaporation on the scaling potential of the RO brine.

\section{Determination of Antiscalants using French Creek}

\section{Software}

The French Creek Software was used to predict the scaling potential, based on the solubility of scale forming species, as well as predict the optimum antiscaling agent for the water sample. The software makes use of multiple saturation and stability indices to accomplish this. The Langelier saturation and Ryzner stability indices are amongst the many that the French Creek software utilizes to give accurate results [57]. The optimum dosage of the proposed antiscalant was also obtained from the software simulation.

\section{RESULTS AND DISCUSSION}

\section{A. Sample Characterization}

The concentrations of the cations of interest in the feed RO brine, being calcium, barium and silicon were determined as $777.491 \mathrm{ppm}, 0.76 \mathrm{ppm}$ and $152.91 \mathrm{ppm}$, respectively. Whereas, the alkalinity as $\mathrm{CaCO}_{3}$ was measured as $132 \mathrm{ppm}$, while the sulfate content was determined to be $3363 \mathrm{ppm}$. The $\mathrm{pH}$ of the feed brine was 8.18 .

\section{B. PHREEQC Modelling}

Modelling in PHREEQC showed that the calcium ion is likely to form calcium sulfate and calcium carbonate at the feed conditions of $18.5^{\circ} \mathrm{C}$ and a $\mathrm{pH}$ of 8.18 . More calcium sulfate is likely to form compared to calcium carbonate. Results also show that barium will not form complexes with free sulfate ions, and amorphous silica $\left(\mathrm{SiO}_{2}\right)$ will not form, at these conditions. Simulating evaporation via PHREEQC yielded an increase in the saturation indices of the common scale forming compounds, depicted in Table I. An evaporation of $34.5 \%$ was simulated (which is the evaporation achieved in our Bench Scale MED [56-57]). This makes it evident that the concentration of scale forming compounds drives the solution closer to supersaturation, and thus precipitation, increasing the potential of scale formation on the surface of heat exchanger. The $\mathrm{pH}$ after evaporation was measured as 9.39 .

TABLE I: SATURATION INDICES OF COMMON SCALE FORMING AGENTS

\begin{tabular}{lll}
\hline Compound & Before evaporation & After evaporation \\
\hline Anhydrite & 0.12 & 0.33 \\
Aragonite & 0.68 & 0.86 \\
Barite & 2.21 & 2.41 \\
Calcite & 0.82 & 1.00 \\
Gypsum & 0.16 & 0.36 \\
Amorphous Silica & 0.3 & 0.48 \\
\hline \hline
\end{tabular}

TABLE II: SATURATION INDICES OF COMMON SCALE FORMING AGENTS

\begin{tabular}{llll}
\hline \hline Compound & $18.5^{\circ} \mathrm{C}$ & $40^{\circ} \mathrm{C}$ & $75^{\circ} \mathrm{C}$ \\
\hline Anhydrite & 0.12 & 0.26 & 0.44 \\
Aragonite & 0.68 & 0.7 & 0.77 \\
Barite & 2.21 & 1.85 & 1.33 \\
Calcite & 0.82 & 0.85 & 0.99 \\
Gypsum & 0.16 & 0.09 & -0.01 \\
Amorphous Silica & 0.3 & 0.07 & -0.25 \\
\hline
\end{tabular}


The behavior of metal species in the sample was also simulated at $75^{\circ} \mathrm{C}$. Table II depicts the increase in saturation indices for an increase in temperature. The saturation indices of calcite and anhydrite showed a direct relationship with temperature, increasing when the temperature of the sample was increased. However, the potential for barite scale to form was decreased when the temperature was increased. This behavior is also seen for gypsum and amorphous silica. This indicates that the combined effect of temperature increase and evaporation that the brine will experience in an MED system makes it highly likely for the formation of scale, if no preventative measures are put in place.

\section{French Creek Software Analysis}

The concentrations of metals obtained from the ICP-OES analysis were used as input for the French Creek software analysis of the feed RO brine. Table III depicts the saturation limits of the common scale forming compounds. Gypsum and barite are above their upper limits of 4.00 and 80.00, respectively. This means that these compounds are highly likely to precipitate out of solution. Additional treatment will be required to remove the barite, as it is highly insoluble and resistant to chemical treatment [60].

TABLE III: LIMITS OF COMMON SCALE FORMING COMPOUNDS

\begin{tabular}{lllll}
\hline \hline Compound & $\begin{array}{l}\text { Saturation } \\
\text { limit }\end{array}$ & $\begin{array}{l}\text { Lower } \\
\text { limit }\end{array}$ & $\begin{array}{l}\text { Upper } \\
\text { limit }\end{array}$ & Status \\
\hline Calcite & 65.41 & N/A & 150.00 & OK \\
Gypsum & 5.53 & N/A & 4.00 & ABOVE LIMIT \\
Celestite & 5.09 & N/A & 12.00 & OK \\
Barite & 396.72 & N/A & 80.00 & ABOVE LIMIT \\
Amorphous & 0.00 & N/A & 1.20 & OK \\
$\begin{array}{l}\text { Silica } \\
\text { Fluorite }\end{array}$ & 5.67 & N/A & 120 & OK \\
Anhydrite & 3.39 & N/A & 4.00 & OK \\
$\begin{array}{l}\text { Aragonite } \\
\text { Langelier }\end{array}$ & 60.50 & N/A & 150.00 & OK \\
Index & 2.28 & N/A & 2.50 & BORDERLINE \\
Ryznar & 3.44 & N/A & 2.80 & ABOVE LIMIT \\
Index & & & & \\
\hline \hline
\end{tabular}

The proposed antiscalants were PMA (polyamaleic acid) and HEDP (1-Hydroxy Ethylidene-1,1-Diphosphonic Acid), which belong to the carboxylic and phosphonate groups, respectively. The recommended dosages were 0.062 and 0.428 ppm for HEDP and PMA, respectively. Phosphonates act in the nucleation and crystallization stages of crystal growth of many sparingly soluble inorganic salts, efficiently hindering these processes. They are also highly stable at elevated temperatures [61]. Additionally, PMA inhibitors do not experience loss of activity due to hydrolysis, and are more hydrolytically stable at high levels of $\mathrm{pH}$. Unfortunately, these polymers have low calcium tolerance and can react to form calcium-polymer salts, which are not soluble [62]. Fig. 1to Fig. 3 illustrates this, as PMA is able to control calcite, anhydrite and gypsum scale at $\mathrm{pH}$ values from 7 to 9 . Whereas HEDP shows a similar trend for calcite, but is able to control anhydrite and gypsum scale at any $\mathrm{pH}$ level (see Fig. 4 to Fig. 5). Calcite is the most thermodynamically stable of the three polymorphs of calcium carbonate, while vaterite is the least stable [63]. Both antiscalants were unable to prevent barite scale formation at any $\mathrm{pH}$. The saturation level of barite did not change over a range of $\mathrm{pH}$ values from 7 to 13 , regardless of whether antiscalants were added or not.

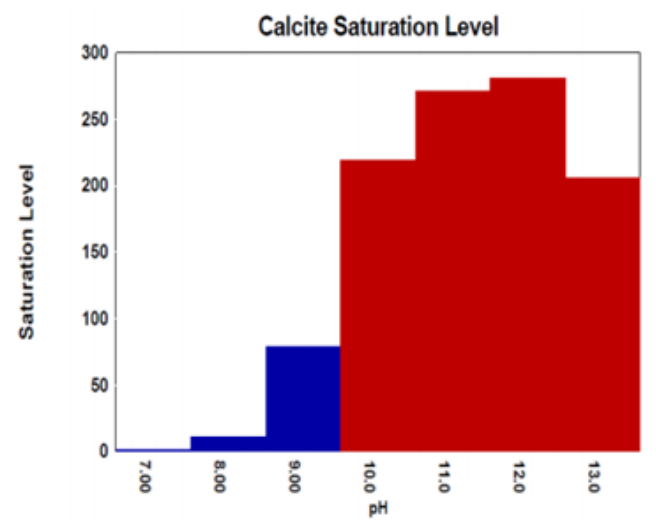

Fig. 1: Saturation level of Calcite vs $\mathrm{pH}$ for PMA (blue - safe range; red - scaling cannot be controlled, remedial action required)

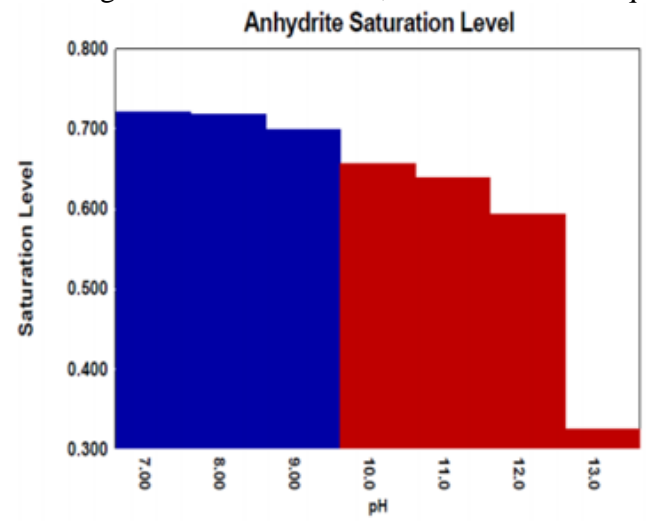

Fig. 2: Saturation level of Anhydrite vs $\mathrm{pH}$ for PMA (blue - safe range; red - scaling cannot be controlled, remedial action required)

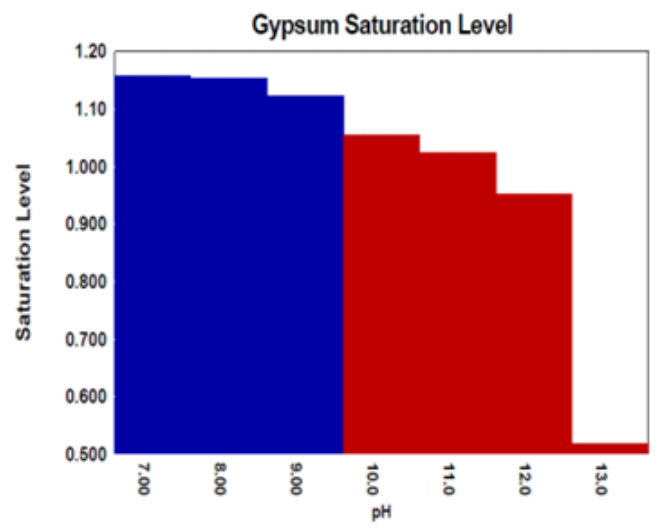

Fig. 3: Saturation level of Gypsum vs $\mathrm{pH}$ for PMA (blue - safe range; red - scaling cannot be controlled, remedial action required) 


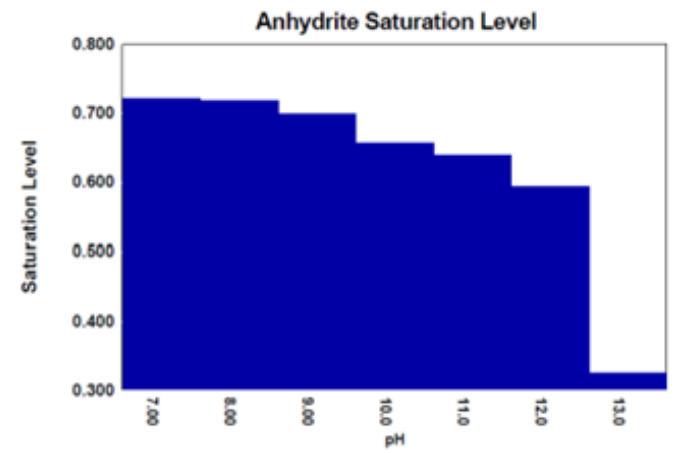

Fig. 4: Saturation level of anhydrite vs $\mathrm{pH}$ for HEDP

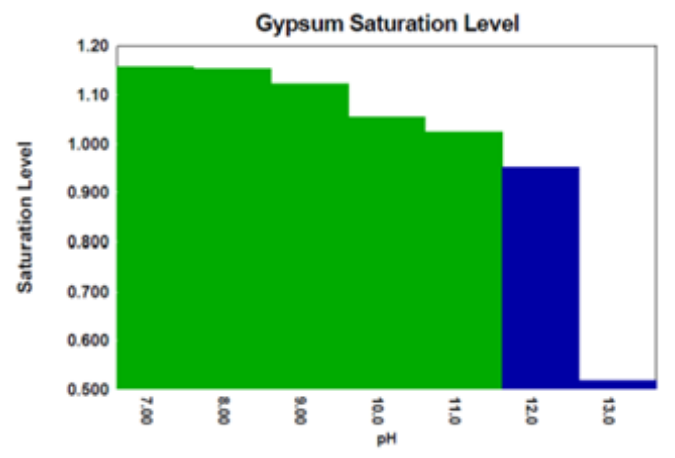

Fig. 5: Saturation level of gypsum vs $\mathrm{pH}$ for HEDP (green - mild problem potential if conditions change slightly)

This gives an indication that the HEDP antiscalant is more flexible than the PMA antiscalant, for the RO brine sample.

\section{CONCLUSION}

RO systems have limitations that necessitate the need for downstream desalination processes that will reduce the large volumes of concentrate produced. Thermal desalination has been successful in doing this, making use of the excess heat from low pressure spent steam in power plants. Scale formation poses a problem in thermal desalination systems, with the common scale forming agents being calcite, gypsum and anhydrite. The gypsum and barite saturation levels in the feed RO brine were above their limits, at 5.53 and 396.72, respectively. Evaporation of the RO brine illustrated an increase in the saturation indices of the common scale forming compounds. The same pattern is seen (for most of the scale forming compounds) for an increase in temperature to $75^{\circ} \mathrm{C}$, which is the usual temperature for the first effect of an MED system. The proposed antiscalants, HEDP and PMA were both able to control scale formation for $\mathrm{pH}$ variations between 7 and 9, but were not able to control barite scale for any $\mathrm{pH}$ value. Additional treatment is required to remove the barite scale. HEDP performed better based on French Creek modelling, as it was able to fully inhibit both anhydrite and gypsum, unlike PMA. The pretreatment of RO brine is necessary because of the high propensity of the feed brine to form scale at conditions that are found in an MED system. To substantiate the viability of the use of antiscalants, the induction tests can be carried out to prove that the antiscalant extends the induction period of the brine, hopefully enough to improve the performance of MED systems.

\section{ACKNOWLEDGMENT}

the authors are grateful to the support from Eskom and the North-West University.

\section{REFERENCES}

[1] Elvis Fosso-Kankeu. 2019. Nano and Bio-based Technologies for wastewater treatment: Prediction and Control Tools for the dispersion of Pollutants in the Environment. Wiley Scrivener. ISBN: 978-1-119-57709-6. Pp 301-336.

[2] Elvis Fosso-Kankeu. 2019. New Horizons in Wastewaters Management: Emerging Monitoring and Remediation Strategies. Nova Science Publishers. ISBN: 978-1-53615-659-1.

[3] J.G. Redelinghuys, E. Fosso-Kankeu, G. Gericke, F. Waanders. 2019. Coal Power Plant Wastewater Treatment by Thermal and Membrane Technologies. In Nano and Bio-based Technologies for wastewater treatment: Prediction and Control Tools for the dispersion of Pollutants in the Environment. Editor: Elvis Fosso-Kankeu. Wiley Scrivener. ISBN: 978-1-119-57709-6. Pp 149-168. https://doi.org/10.1002/9781119577119.ch5

[4] N. Mukwevho, E. Fosso-Kankeu, F. Waanders. 2019. PAHs Released from Coal Tars and Potential Removal Using Nanocatalysts. In Nano and Bio-based Technologies for wastewater treatment: Prediction and Control Tools for the dispersion of Pollutants in the Environment. Editor: Elvis Fosso-Kankeu. Wiley Scrivener. ISBN: 978-1-119-57709-6. Pp 169-203. https://doi.org/10.1002/9781119577119.ch6

[5] Nthambeleni Mukwevho, Elvis Fosso-Kankeu, Frans Waanders, Neeraj Kumar, Suprakas Sinha Ray, Xavier Yangkou Mbianda. 2019. Evaluation of the photocatalytic activity of $\mathrm{Gd}_{2} \mathrm{O}_{2} \mathrm{CO}_{3} . \mathrm{ZnO} . \mathrm{CuO}$ nanocomposite used for the degradation of phenanthrene. Springer Nature Applied Sciences. https://doi.org/10.1007/s42452-018-0012-0. $1-10$.

[6] Fosso-Kankeu E., Potgieter J. and Waanders F.B. 2019. Removal of malachite green and toluidine blue dyes from aqueous solution using a clay-biochar composite of bentonite and sweet sorghum bagasse. International Journal of Applied Engineering Research. 14(6): 1324-1333.

[7] Johannes Cornelius van der Linde, Elvis Fosso-Kankeu, Gerhard Gericke, Frans Waanders, Louise Dreyer, Nico Lemmer. 2019. Flocculant types and operating conditions influencing particles settling rates in feed water used at a coal power plant. Desalination and Water Treatment. 150: 293-300. https://doi.org/10.5004/dwt.2019.23735

[8] E Fosso-Kankeu, R Weideman, D Moyakhe, FB Waanders, M Le Roux, QP Campbell. 2019. Hydrothermal preparation of biochar from spent coffee grounds, and its application for the removal of cadmium from coal tailings leachate. The Journal of the Southern African Institute of Mining and Metallurgy. 119: 607-612. https://doi.org/10.17159/2411-9717/449/2019

[9] R Gusain, N Kumar, E Fosso-Kankeu, SS Ray. 2019. Efficient removal of $\mathrm{Pb}$ (II) and $\mathrm{Cd}(\mathrm{II})$ from industrial mine water by a hierarchical MoS2/SH-MWCNT nanocomposite. ACS Omega. 4: 13922-13935. https://doi.org/10.1021/acsomega.9b01603

[10] Nthambeleni Mukwevho, Rashi Gusain, Elvis Fosso-Kankeu, Neeraj Kumar, Frans Waanders, Suprakas Sinha Ray. 2019. Removal of naphthalene from simulated wastewater through adsorption-photodegradation by $\mathrm{ZnO} / \mathrm{Ag} / \mathrm{GO}$ nanocomposite. Journal of Industrial and Engineering Chemistry. https://doi.org/10.1016/j.jiec.2019.09.030

[11] Erdogan IC, Fosso-Kankeu E, Ntwampe SKO, Waanders FB, Hoth N, Rand A, Farrar TJ. 2019. Households water quality in O'kiep - South Africa and community perception of related health risks. 167(2019): $145-155$. https://doi.org/10.5004/dwt.2019.24576

[12] N Kumar, E Fosso-Kankeu, SS Ray. 2019. Achieving controllable MoS2 nanostructures with increased interlayer spacing for efficient removal of $\mathrm{Pb}$ (II) from aquatic systems. ACS Applied Materials and Interfaces. 11: 19141-19155. 
https://doi.org/10.1021/acsami.9b03853

[13] IG Erdogan, E Fosso-Kankeu, SKO Ntwampe, FB Waanders, N Hoth and A Rand. 2019. Acid rock drainage prediction of metalliferous soils from O'kiep, Namaqualand, South Africa: A humidity cell test assessment. IMWA 2019 Conference "Mine Water - Technological and Ecological Challenges". 15-19 July 2019, Perm, Russia. Elena Khayrulina and Christian Wolkersdorfer. ISBN: 978-5-91252-145-4. Pp 613-618.

[14] E Fosso-Kankeu, R Weideman, D Moyakhe, F Waanders, Q Campbell. 2019. Thermodynamic study of the adsorption performance of spent coffee beans for the removal of cadmium from coal tailing leachates. IMWA 2019 Conference "Mine Water - Technological and Ecological Challenges". 15-19 July 2019, Perm, Russia. Elena Khayrulina and Christian Wolkersdorfer. ISBN: 978-5-91252-145-4. Pp 184-188.

[15] E. Fosso-Kankeu, P. Jagals, H. Du Preez, Exposure of rural households to toxic cyanobacteria in container-stored water. Water SA, Vol. 34, no. 5 , pp. 631-636, 2008 https://doi.org/10.4314/wsa.v34i5.180660

[16] E. Fosso-Kankeu, A. Mulaba-Bafubiandi, B.B. Mamba, T.G. Barnard, Mitigation of $\mathrm{Ca}, \mathrm{Fe}$, and $\mathrm{Mg}$ loads in surface waters around mining areas using indigenous microorganism strains. Journal of Physics and Chemistry of the Earth, Vol. 34, pp. 825-829, 2009. https://doi.org/10.1016/j.pce.2009.07.005

[17] E. Fosso-Kankeu, H. Du Preez, P. Jagals, The health implication of relationships between bacterial endotoxin, cyanobacteria, coliforms and water stored in domestic containers of rural households in South Africa. Journal of Water and Health, Vol. 8, no. 4, pp. 601-610, 2010. https://doi.org/10.2166/wh.2010.094

[18] E. Fosso-Kankeu, A. Mulaba-Bafubiandi, B.B. Mamba, L. Marjanovic, T.G. Barnard, A comprehensive study of physical and physiological parameters that affect biosorption of metal pollutants from aqueous solutions. Journal of Physics and Chemistry of the Earth, Vol. 35, pp. 672-678, 2010. https://doi.org/10.1016/j.pce.2010.07.008

[19] E. Fosso-Kankeu, A.F. Mulaba-Bafubiandi, B.B. Mamba and T.G. Barnard, Prediction of metal-adsorption behaviour in the remediation of water contamination using indigenous microorganisms. Journal of Environmental Management. Vol. 92, no. 10, pp. 2786-2793, 2011. https://doi.org/10.1016/j.jenvman.2011.06.025

[20] H. Mittal, E. Fosso-Kankeu, Shivani B. Mishra, Ajay K. Mishra, Biosorption potential of Gum ghatti-g-poly (acrylic acid) and susceptibility to biodegradation by B. subtilis. International Journal of Biological Macromolecules. Vol. 62, pp. 370-378, 2013. https://doi.org/10.1016/j.ijbiomac.2013.09.023

[21] E. Fosso-Kankeu, H. Mittal, F. Waanders, I.O. Ntwampe, S.S. Ray, Preparation and characterization of gum karaya hydrogel nanocomposite flocculant for metal ions removal from mine effluents. International Journal of Environmental Science and Technology. Vol. 13, pp. 711-724, 2016. https://doi.org/10.1007/s13762-015-0915-x

[22] E. Fosso-Kankeu, F. Waanders, E. Maloy, Copolymerization of ethyl acrylate onto guar gum for the adsorption of $\mathrm{Mg}$ (II) and $\mathrm{Ca}$ (II) ions. Desalination and Water Treatment. doi: 10.1080/19443994.2016.1165147: pp. 1-10, 2016.

[23] E. Fosso-Kankeu, F. Waanders, C.L. Fourie, Adsorption of Congo Red by surfactant-impregnated bentonite clay. Desalination and Water Treatment. doi: 10.1080/19443994.2016.1177599: pp. 1-9, 2016.

[24] E. Fosso-Kankeu, A. Manyatshe, F. Waanders, Mobility potential of metals in acid mine drainage occurring in the Highveld area of Mpumalanga Province in South Africa: Implication of sediments and efflorescent crusts. International Biodeterioration and Biodegradation. Vol. 119, pp. 661-670, 2017. https://doi.org/10.1016/j.ibiod.2016.09.018

[25] E. Fosso-Kankeu, H. Mittal, F. Waanders, S.S. Ray, Thermodynamic properties and adsorption behaviour of hydrogel nanocomposites for cadmium removal from mine effluents. Journal of Industrial and Engineering Chemistry. Vol. 48, pp. 151-161, 2017. https://doi.org/10.1016/j.jiec.2016.12.033

[26] E. Fosso-Kankeu, F.B. Waanders, F.W. Steyn, Removal of $\mathrm{Cr}(\mathrm{VI})$ and $\mathrm{Zn}$ (II) from an aqueous solution using an organic-inorganic composite of bentonite-biochar-hematite. Desalination and Water Treatment. Vol. 59, pp. 144-153, 2017.

https://doi.org/10.5004/dwt.2017.0059
[27] A. Manyatshe, E. Fosso-Kankeu, D. van der Berg, N. Lemmer, F. Waanders, H. Tutu, Dispersion of inorganic contaminants in surface water in the vicinity of Potchefstroom. Physics and Chemistry of the Earth. Vol. 100, pp. 86-93, 2017. https://doi.org/10.1016/j.pce.2017.04.008

[28] C. de Klerk, E. Fosso-Kankeu, F.B. Waanders, Evaluation of the antibacterial activity of metal impregnated multi-walled carbon nanotubes: impact of domestic wastewater as supporting medium. Desalination and Water Treatment.Vol. 99, pp. 272-281, 2017. https://doi.org/10.5004/dwt.2017.21735

[29] L.P. Simelane, E. Fosso-Kankeu, P. Njobeh, S. Pandey, Response of bacterial biosorbents to chemical treatment as influenced by cell membrane structure and impact on the adsorption behaviour of dyes. Current Science. Vol. 114, no. 4, pp. 826-834, 2018. https://doi.org/10.18520/cs/v114/i04/826-834

[30] Pouris, A. and Thiopil, G. (2015) Long term forecasts of water usage for electricity generation: South Africa 2030

[31] Thopil, G.A. and Pouris, A., 2016. A 20 year forecast of water usage in electricity generation for South Africa amidst water scarce conditions. Renewable and Sustainable Energy Reviews, 62, pp.1106-1121. https://doi.org/10.1016/j.rser.2016.05.003

[32] Wassung, N., 2010. Water scarcity and electricity generation in South Africa (Doctoral dissertation, Stellenbosch: University of Stellenbosch).

[33] Schulz, M. and Northrup, C. (2014) 'Balancing the business of energy and water', Water Wheel, 13(1), pp. 36-38.

[34] Tong, T. and Elimelech, M. (2016) 'The Global Rise of Zero Liquid Discharge for Wastewater Management: Drivers, Technologies, and Future Directions', Environmental Science and Technology, 50(13), pp. 6846-6855. doi: 10.1021/acs.est.6b01000

[35] Oren, Y. et al. (2010) 'Pilot studies on high recovery BWRO-EDR for near zero liquid discharge approach', Desalination. Elsevier B.V., 261(3), pp. 321-330. doi: 10.1016/j.desal.2010.06.010.

[36] Shaffer, D. L. et al. (2013) 'Desalination and reuse of high-salinity shale gas produced water: Drivers, technologies, and future directions', Environmental Science and Technology, 47(17), pp. 9569-9583. doi: 10.1021/es401966

[37] Trieb, F., Moser, M. and Fichter, T. (2011) 'MENA Regional Water Outlook', Desalination Using Renewable Energy, (February). Available at: http://elib.dlr.de/72591/1/Workshop_Oman_Final_DLR.pdf

[38] Roos, T. H., Rogers, D. E. C. and Gericke, G. (2017) 'Solar-assisted MED treatment of Eskom power station waste water', AIP Conference Proceedings, 1850(June). doi: 10.1063/1.4984567.

[39] Ariono, D., Purwasasmita, M. and Wenten, I. G. (2016) 'Brine Effluents: Characteristics, Environmental Impacts, and Their Handling', Journal of Engineering and Technological Sciences, 48(4), pp. 367-387. doi: 10.5614/j.eng.technol.sci.2016.48.4.1.

[40] Giwa, A. et al. (2017) 'Brine management methods: Recent innovations and current status', Desalination. Elsevier B.V., 407, pp. 1-23. doi: 10.1016/j.desal.2016.12.008.

[41] Subramani, A. and Jacangelo, J. G. (2014) 'Treatment technologies for reverse osmosis concentrate volume minimization: A review', Separation and Purification Technology. Elsevier B.V., 122, pp. 472-489. doi: 10.1016/j.seppur.2013.12.004.

[42] Wildebrand, C. et al. (2007) 'Effects of process parameters and anti-scalants on scale formation in horizontal tube falling film evaporators', Desalination, 204(1-3 SPEC. ISS.), pp. 448-463. doi: 10.1016/j.desal.2006.03.547.

[43] Semblante, G. U. et al. (2018a) 'Brine pre-treatment technologies for zero liquid discharge systems', Desalination. Elsevier, 441(April), pp. 96-111. doi: 10.1016/j.desal.2018.04.006.

[44] Lisitsin, D. et al. (2005) 'Inhibition of $\mathrm{CaCO} 3$ scaling on $\mathrm{RO}$ membranes by trace amounts of zinc ions', Desalination, 183(1-3), pp. 289-300. doi: 10.1016/j.desal.2005.10.002.

[45] Semblante, G. U. et al. (2018b) 'Brine pre-treatment technologies for zero liquid discharge systems', Desalination. Elsevier, 441(January), pp. 96-111. doi: 10.1016/j.desal.2018.04.006

[46] Sheikholeslami, R. (2003) 'Nucleation and kinetics of mixed salts in scaling', AIChE Journal, 49(1), pp. 194-202. doi: 10.1002/aic.690490117.

[47] Al-Rawajfeh, A. E. et al. (2015) 'Inhibitory effect of Hydrex anti-scalant on calcium scale deposition from seawater under multiple-effect 
distillers' conditions', Water Resources and Industry. Elsevier, 11, pp. 58-63. doi: 10.1016/j.wri.2015.07.001.

[48] Shakkthivel, P. and Vasudevan, T., 2006. Acrylic acid-diphenylamine sulphonic acid copolymer threshold inhibitor for sulphate and carbonate scales in cooling water systems. Desalination, 197(1-3), pp.179-189. https://doi.org/10.1016/j.desal.2005.12.023

[49] Hamed, O. A. et al. (2000) 'Evaluation of polyphosphonate antiscalant at a low dose rate in the Al-Jubail Phase II MSF plant, Saudi Arabia', Desalination, 128(3), pp. 275-280. doi: 10.1016/S0011-9164(00)00042-4.

[50] Falini, G., Fermani, S., Tosi, G. and Dinelli, E. (2009) 'Calcium carbonate morphology and structure in the presence of seawater ions and humic acids' (2009) Crystal Growth and Design, 9(5), pp. 2065-2072. doi: $10.1021 / \mathrm{cg} 8002959$.

[51] Fosso-kankeu, E., Brider, C. E., Redelinghuys, J., Gericke, G., Lemmer, N., \& Waanders, F. (2018). Determination of Suitable Anti-Scaling Agent to Inhibit Scale Formation of Water Processed in Coal Power Plant System. 30-36. https://doi.org/10.17758/eares.eap1117017.

[52] E. Fosso-Kankeu, F. Waanders, R. Swiegers, I.O. Ntwampe, D. Rogers, G. Gericke, Impact of the physico-chemical properties of water on the flocculation performance of lime, clay and other polymers. International Conference on Advances in Science, Engineering, Technology and Natural Resources (ICASETNR-16) Nov. 24-25, 2016, Parys - South Africa. ISBN: 978-93-84468-79-8. 2016.

[53] JC van der Linde, E Fosso-Kankeu, G Gericke, F Waanders and T. Tamane. 2018. Effect of Temperature on the Performance of Rheofloc: Conductivity Removal from RO-reject. Editors: Elvis Fosso-Kankeu, Frans Waansders, Michel Plaisent. 10th Int'l Conference on Advances in Science, Engineering, Technology \& Healthcare (ASETH-18) Nov. 19-20, 2018 Cape Town (South Africa). ISBN: 978-81-938365-2-1. Vol II. Pp 139-143.

[54] E. Fosso-Kankeu, L. Van Schalkwyk, J. Van Der Linde, G. Gericke and F.B. Waanders. 2018. Pretreatment of Coal Power Plant RO Retentate using AR Floc 100. Editors: Elvis Fosso-Kankeu, Frans Waansders, Michel Plaisent. 10th Int'l Conference on Advances in Science, Engineering, Technology \& Healthcare (ASETH-18) Nov. 19-20, 2018 Cape Town (South Africa). ISBN: 978-81-938365-2-1. Vol II. Pp 149-154.

[55] E. Fosso-Kankeu, F.B. Waanders, G. Gericke, N. Lemmer, L.M. Dreyer and J. van der Linde, Investigation of the potential of monomeric and polymeric coagulants in the treatment of raw water used at a coal-fired power station. $9^{\text {th }}$ Int'l Conference on Advances in Science, Engineering, Technology \& Waste Management (ASETWM-17). 27-28 November 2017, Parys, South Africa. Editors: F. Waanders, E. Fosso-Kankeu, B. Topcuoglu, M. Plaisent, Y. Thaweesak. ISBN: 978-81-934174-6-1. Pp. 44-48. 2017.

[56] Redelinghuys, J., Waanders, F., Rogers, D., Bruinsma, D., \& Gericke, G. (2017). Determination of Water Evaporation Rate in an Assembled Bench Scale MED and Impact of Anti-Scaling Agents on the Morphology of Scale. 10-14. https://doi.org/10.15242/iae.iae1116405

[57] Redelinghuys, J., Waanders, F., Rogers, D., \& Gericke, G. (2018). Scaling Conditions Inside Improved Bench-Scale Single Effect Vacuum Evaporator. 2-7. https://doi.org/10.17758/eares.eap1117035.

[58] Manyatshe, A., Fosso-Kankeu, E., van der Berg, D., Lemmer, N., Waanders, F., \& Tutu, H. (2017). Metal Speciation in the Rivers Around Potchefstroom Based on Seasonality. Water Environment Research, 90(1), 84-95. https://doi.org/10.2175/106143017x15054988926587.

[59] Fosso-Kankeu, E., Manyatshe, A., \& Waanders, F. (2017). Mobility potential of metals in acid mine drainage occurring in the Highveld area of Mpumalanga Province in South Africa: Implication of sediments and efflorescent crusts. International Biodeterioration and Biodegradation, 119, 661-670. https://doi.org/10.1016/j.ibiod.2016.09.018.

[60] Bukuaghangin, O., Sanni, O., Neville, A. and Charpentier, T., 2016, June. A Kinetic Study of Barium Sulphate Formation in Presence of Scale Inhibitor in a Flowing System. In Proceedings of a meeting held 6-10 March 2016, Vancouver, Canada (Vol. 5, pp. 3398-3411). NACE International.

[61] Peters, E.M., 2015. Effect of antiscalants during eutectic freeze crystallization of a reverse osmosis retentate (Doctoral dissertation, University of Cape Town).

[62] Amjad, Z. (1996) 'Scale Inhibition in Desalination Applications: An Overview', Corrosion, NACE, pp. 96-230.
[63] Tang, Y. et al. (2008) 'Investigation of $\mathrm{CaCO} 3$ scale inhibition by PAA, ATMP and PAPEMP', Desalination, 228(1-3), pp. 55-60. doi: 10.1016/j.desal.2007.08.006. 